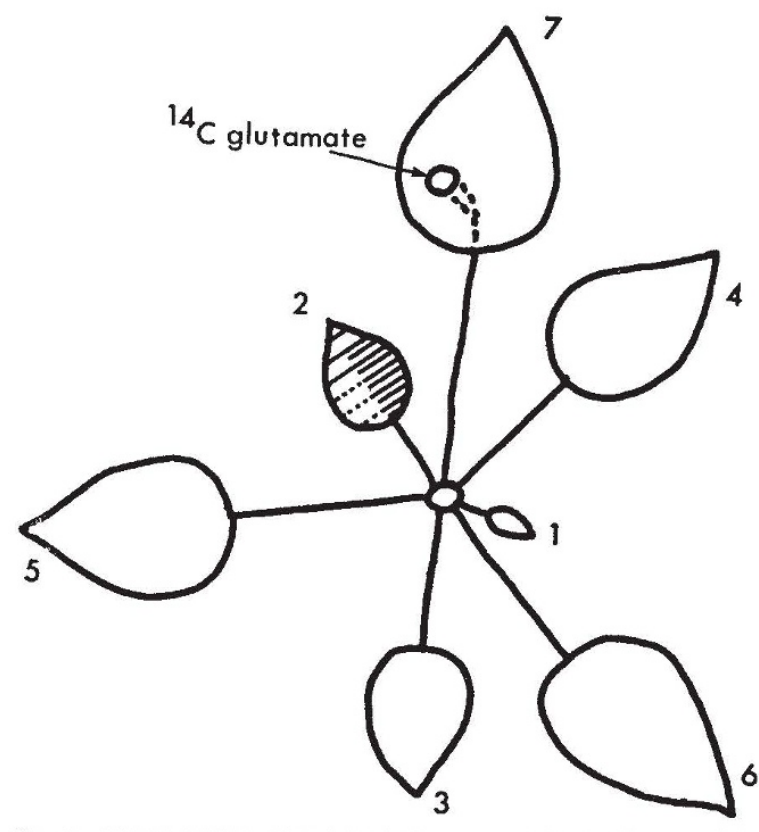

Fig. 1. Translocation of carbon-14 to a young leaf after supplying carbon-14-labelled glutamate to a mature leaf of beet for $18 \mathrm{~h}$. The glutamate solution was placed in a small well (a ring of 'Tygon' tubing) sealed to the leaf with lanolin, and covered with cellulose acetate film to
restrict evaporation. Diagram based on autoradiographs

are quite different from those of xylem transport. It remains to be shown whether phloem translocation of amino-acids can contribute a significant amount of nitrogen for young leaf growth.

K. W. Jox*

A. J. Antcliff $\dagger$

Department of Plant Physiology,

Imperial College of Science and Technology,

London, S.W.7. * Present address: Department of Botany, University of Toronto, Canada.
+ Present address: C.S.I.R.O. Horticultural Research Section, Merbein, Victoria, Australia.

${ }^{1}$ Brennen, H., Pate, J. S., and Wallace, W., Ann. Bot., N.S., 28, 527 (1964).

2 Pate, J. S., Wallace, W., and Van Die, J., Nature, 204, 1073 (1964).

${ }^{3}$ Peel, A. J., and Weatherley, P. E., Nature, 184, 1955 (1959).

${ }^{4}$ Joy, K. W., Nature, 195, 618 (1962).

${ }^{5}$ Joy, K. W., J. Exp. Bot., 15, 485 (1964).

\section{Variations in Gestation Length of Mink (Mustela vison)}

MiNk reproduction is characterized by several remarkable features, among which the variability of gestation length is of outstanding interest. Hansson ${ }^{1}$ and Enders ${ }^{2}$ have emphasized this variability (from 37 to 91 days) in thoir classic studies on mink reproduction. It is generally accepted that this range in gestation length is due to varying periods of delayed implantation, when the fertilized ova reside in the uterus for an extended poriod of time before nidation occurs. This communication reports some investigations which I made of the normal variations of gestation length in four modern colour phases (strains) of mink and the effects of the age of the female, the date of mating and litter size on gestation length.

Ninety mink of the four colour pheses were used. The genetic formulae of these colour phases were: 'Pearl' (pp bpbp alal), 'Cameo' (alal bm $m^{H} b m^{H}$ ), 'Dawn Pastel' $(b b \quad b s b s)$ and 'Violet' ( $p p$ alal bmbm). The mink were raised under normal ranch conditions in the Great Lakes region of the United States. All mink received a standard ration consisting of 55 per cent meat, 12 per cent cereal and 33 per cent water. This ration was supplemented with vitamin $A(1,560,000$ r.U. per ton of dry feed) and a bacterial-fungal enzyme (Nopco Chemical Co., Harrison, New Jersey) (1.8 kg per ton of dry feed). Some of the
Table 1. Gestation Length of Yearing and Older Mrnk of Four Colour PHASES
No. of Mean gestation
Festations length (days)

\begin{tabular}{|c|c|c|}
\hline (1) Colout & & \\
\hline (a) 'Pearl', & 41 & $52 \cdot 5 \pm 4 \cdot 0$ \\
\hline $\begin{array}{l}\text { (b) 'Cameo' } \\
\text { (c) 'Tawn Pastel' }\end{array}$ & 20 & $50 \cdot 8 \pm 5 \cdot 2$ \\
\hline $\begin{array}{l}\text { (c) 'Dawn Pastel' } \\
\text { (d) 'Violet' }\end{array}$ & $\begin{array}{r}22 \\
7\end{array}$ & $\begin{array}{l}53 \cdot 3 \pm 3 \cdot 9 \\
52 \cdot 0 \pm 5 \cdot 1\end{array}$ \\
\hline $\begin{array}{l}\text { (2) Age of female } \\
\text { (a) Yearling }\end{array}$ & 60 & $52 \cdot 0 \pm$ \\
\hline & & \\
\hline
\end{tabular}

Table 2. Gestation Length of Mink based on Time of Breeding

$\begin{array}{ccc}\text { Date of breeding } & \begin{array}{c}\text { No. of } \\ \text { gestations }\end{array} & \begin{array}{c}\text { Mean gestation } \\ \text { length (days) }\end{array} \\ \text { March 10-14 } & 12 & 56 \cdot 8 \pm 2 \cdot 3 \\ \text { March 15-19 } & 46 & 53 \cdot 0 \pm 2 \cdot 7 \\ \text { March 20-24 } & 25 & 50 \cdot 3 \pm 4 \cdot 5 \\ \text { March 25-29 } & 7 & 46 \cdot 4 \pm 4 \cdot 4\end{array}$

Table 3. Gestation Length of Mink in Relation to Littikn Size

$\begin{array}{cccc}\begin{array}{c}\text { Gestation length } \\ \text { range (days) }\end{array} & \begin{array}{c}\text { No. of } \\ \text { gestations }\end{array} & \begin{array}{c}\text { Mean gestation } \\ \text { length (days) }\end{array} & \begin{array}{c}\text { Mean litter } \\ \text { size }\end{array} \\ 42-45 & 8 & 43 \cdot 1 & 4 \cdot 00 \pm 1 \cdot 82 \\ \mathbf{4 6}-49 & 11 & 47 \cdot 5 & 4 \cdot 00 \pm 2 \cdot 14 \\ 50-53 & 33 & 51 \cdot 5 & 3 \cdot 88 \pm 2 \cdot 18 \\ 54-57 & 29 & 55 \cdot 1 & 3 \cdot 59 \pm 2 \cdot 21 \\ 58-61 & 9 & 58 \cdot 7 & 3 \cdot 33 \pm 1 \cdot 66\end{array}$

mink received an additional supplement of ethylene dichloride extracted wheat germ oil $\left(\right.$ Dukelow $\left.^{3}\right)$. This treatment did not significantly affect gestation length, and therefore data from mink receiving this treatment were pooled with data from untreated mink.

Matings were started on March 10, 1963. All females were mated only once and did not accept mating at a later date. Because of this procedure it can be assumed that these mink were of higher fertility than the remainder of the herd which afterwards accepted a later mating. The gestation length was measured from the date of mating to the date of birth. All data were treated by analysis of variance. Differences in gestation length between colour phases and yearling and aged females were not statistically significant (Table 1). Hansson ${ }^{1}$ reported gestation length means of $51 \cdot 3 \pm 5 \cdot 4$ days for 'Eastern' mink and $49 \cdot 0 \pm$ 4.2 days for 'Alaskan' mink. The lack of a significant difference between yearling and older mink in gestation length is in agreement with Apelgren ${ }^{4}$, but conflicts with Enders ${ }^{2}$, who believed that the gestation length was longer in yearlings than in the same individuals when older. A highly significant difference $(P<0.01)$ was observed between gestation lengths based on the date of mating (Table 2). Generally, the later in the breeding season that mating occurred, the shorter was the gestation period.

Hansson ${ }^{1}$ reported that the length of gestation decreases greatly when the date of mating is moved forward. He also reported a decrease in gestation length from matings on March 10-March 29 of $6 \cdot 5$ days compared with $10 \cdot 4$ in the present investigations. Table 3 illustrates the relationship between the length of the gestation period and the number of kits born. The shorter gestations tended to be associated with larger litters. Hansson ${ }^{1}$ showed a similar but irregular tendency. The cause of this phenomenon is not known. Early workers believed that the presence of a larger number of foetuses resulted in an earlier stimulus to parturition and a shorter gestation length. However, modern endocrinological theories of the onset of parturition are in conflict with this. A more logical explanation lies in the higher mortality of zygotes during the period of delayed implantation associated with longer gestations.

I thank Mr. Noble Hall, Woodland Mink Ranch, Grand Rapids, Minnesota, for his assistance and co-operation in these studies.

\section{W. Richard Dukelow}

Department of Biochemistry,

University of Georgia,

Athens, Georgia.

${ }^{1}$ Hansson, A., Acta Zool., 28, 1 (1947).

2 Enders, R. K., Proc. Amer. Phil. Soc., 96, 691 (1952).

3 Dukelow, W. R., J. Reprod. and Fertil. (in the press).

4 Apelgren, R., Vara Pälsdjur, 12, 349 (1941). 